Original Research Paper

\title{
The Effect of Vessel Speed on Fuel Consumption and Exhaust Gas Emissions
}

\author{
${ }^{1}$ Ayudhia P. Gusti and ${ }^{2}$ Semin \\ ${ }^{1}$ Post Graduate Program of Marine Technology, Institut Teknologi Sepuluh Nopember, Surabaya 60111, Indonesia \\ ${ }^{2}$ Department of Marine Engineering, Institut Teknologi Sepuluh Nopember, Surabaya 60111, Indonesia
}

Article history

Revised: 09-11-2016

Accepted: 24-11-2016

Corresponding Author:

Semin

Department of Marine

Engineering, Institut Teknologi

Sepuluh Nopember, Surabaya

60111, Indonesia

Email:semin@its.ac.id
Received: 08-10-2016

\begin{abstract}
High consumption of fuel and emissions from ships has brought a new perspective tospeed optimization of ship. The reducing in fuel consumption can provide higher savings on the total cost of the vessel. Some regulations on environmental issues have been designated by International Maritime Organization (IMO) and other bodies. This research is based on the development of speed optimization. With case studies of MV. Meratus Mamiri which serving routes of $\mathrm{Tj}$. Priok port$\mathrm{Tj}$. Perak port, Indonesia. The result of this study expected reduce the fuel consumption and emission of the ship based on speed optimization.
\end{abstract}

Keywords: Ship Emission, Ship Fuel Consumption, Speed Optimization, Time Window

\section{Introduction}

The transportation using ship is one of the main modes of transportation, with a cost effective option for large volume transport in Indonesia. Generally, there are three types of shipping businesses or services on maritime transport, those are linear service, tramper/charter service and industrial shipping.

The difference between the three types of the shipping businesses is not clearly delineated. A ship can change from one kind of type into another type. It depends by whom the vessel is operated. Each type of cruise has an assortment of its own problems in the operation. One of the problems that must be faced by the ship's owner is to determine the amount of the cost of fuel. Valentino et al. (2012) has shown that the biggest operational cost in ship is the cost of fuel as shown in Table 1. Due to the costs incurred for fuel, the question arises how to reduce the cost of bunker to the ship so the expenditure for fuel can be reduced.

For such a system, something related to energy use must be environmentally friendly and low maintenance. Similar results were reported recently (Yuan and $\mathrm{Bi}, 2015$ ). Reducing operating cost still remains a major problem that must be facing by a company. Both shipping companies and other public companies (Bi et al., 2015; Yuan et al., 2014).
Table 1. Percentage of vessel operating cost

\begin{tabular}{lc}
\hline Cost type & Cost (\%) \\
\hline Fuel & 47 \\
Insurance etc. & 7 \\
Port & 46 \\
\hline
\end{tabular}

The reducing of fuel costs can provide higher savings on the total cost of the vessel. Many methods are taken by shipping companies to reduce fuel consumption. One of the alternatives is sailing at low speeds. Due to the non-linear relationship between speed and fuel consumption, it is clear that a ship with running slower would consume less fuel than the ships that run faster. Each ship in the fleet has a service speed which is normally used by shipping companies to planning routes and docking schedules. However, in reality, the ship can sail at a speed of others as well. A ship has a minimum and maximum speed which determines the speed range while sailing.

Semin et al. (2008a; 2008b; 2008c; 2008d; 2008e; 2009a; 2009b; 2009c; 2009d; 2010; 20015; Semin, 2012; 2015a; 2005b; Semin and Bakar, 2013; 2014) stated that in recent years, rising fuel prices, declining market conditions and environmental issues in terms of air emissions.Similar results were reported recently (Ismail et al., 2008a; 2008b) Environmental issues from ships have brought a new perspective to speed optimization of the ship. Psaraftis and Kontovas (2014) 
reported thatsome regulations on environmental issues has been designated by International Maritime Organization (IMO) and other bodies. The regulation covers the whole range of technical operations up to market and environmental issues of emissions of Green House (GHG) such as carbon dioxide $\left(\mathrm{CO}_{2}\right)$, a gas nongreenhouse gases such as sulfur oxides ( $\mathrm{SOx}$ ), nitrogen oxides (NOx), Particulate Matter (PM) and others. For that in addition to being more efficient from an economic perspective, the vessel must also be environmentally friendly in terms of air emissions.

The main purpose of this paper is to clarify that ship speed affect the amount of fuel consumption and exhaust gas emissions.

\section{Relation of Vessel Speed, Fuel Consumption and Emissions}

Ships sailing has a distance (s) and a specific time because it will affect to the cost of fuel consumption, where it is highly dependent on the speed. The problem is, sailing ships have a certain time window. Norstad et al. (2010) stated that when the ship arrives at the port prior to the schedule it will be fined, as well as if the ship passed through the service schedule will be fined as well. Thus, in cruising mode, ship can be set when running at high speed and when the ship running at low speed. To calculate the fuel consumption of each route with a speed it is used function of engine power, specific fuel consumption and duration of the cruise. To calculate the duration of the journey the vessel can use Equation 1 as below.

$$
t=S / v
$$

Where:

$t=$ The trip duration of ship (hour)

$S=$ The distance between ports (nm)

$v=$ The speed of the ship $(\mathrm{km} / \mathrm{h})$

\section{Estimation of Fuel Consumption}

Fuel is the main energy source of main engine on ship. In the shipping industry, there are several types of fuel include, Heavy Fuel Oil (HFO), Marine Diesel Oil (MDO), Marine Gas Oil (MGO) and biodiesel. The fuel system is a system that is used to supply fuel to the main engine. In general, it consists of three systems that is the transfer system, separating system and the fuel feed system.

The calculation of fuel consumption of engines used formula as in Equation 2.

$F C=B H P x S F O C x t$

Where:

$$
\begin{aligned}
& F C=\text { Fuel consumption }(\mathrm{gr}) \\
& B H P=\text { The main engine power }(\mathrm{kW}) \\
& \text { SFOC } \\
& t \\
& t=\text { The Specific Fuel Oil Consumption }(\mathrm{g} / \mathrm{kWh}) \\
&
\end{aligned}
$$

\section{Estimation of Ship Exhaust Gas}

Fagerholt et al. (2010) reported that the beginning of the $21 \mathrm{st}$ century has been marked by increasing awareness of the effects of the use of fuel to the operating costs and $\mathrm{CO}_{2}$ emissions. The main source of emissions from ships is the exhaust gases from the burning of fuel in the ship's engine. After ignition in the engine, air and fuel mixture releases energy to be harnessed mechanical propulsion systems and produces hot flue gases as a byproduct. Lindstad et al. (2015) stated that exhaust gasses, carbon dioxide $\left(\mathrm{CO}_{2}\right)$ only has the effect of climate, while carbon monoxide (CO), sulfur oxides $\left(\mathrm{SO}_{\mathrm{X}}\right)$, nitrogen oxides $\left(\mathrm{NO}_{\mathrm{X}}\right)$, methane $\left(\mathrm{CH}_{4}\right)$, carbon black $(\mathrm{BC})$ and organic carbon $(\mathrm{OC})$ has the impact on the climate and the environment both locally and regionally harmful, for example on human health. Similar results were reported recently (Eide et al., 2013). The current rules provide for $\mathrm{CO}_{2}$ emission limits on climate change and $\mathrm{NO}_{\mathrm{X}}$ and $\mathrm{SO}_{\mathrm{X}}$ to human health and environmental impacts. To that end, significant regulatory activity has occurred within the International Maritime Organization (IMO) and other bodies. Some regulations on environmental issues has been designated the International Maritime Organization (IMO) and other bodies.

Table 2. Emission factor of pollutant (kg per ton fuel) and the type of ship engines

\begin{tabular}{lllllll}
\hline Engine Type & $\mathrm{NO}_{\mathrm{x}}$ & $\mathrm{CO}$ & $\mathrm{CO}_{2}$ & $\mathrm{VOC}$ & $\mathrm{PM}$ & $\mathrm{SO}_{\mathrm{x}}$ \\
\hline Steam turb.-BFO & 6,98 & 0,431 & 3200 & 0,085 & 2,5 & $20 \mathrm{~s}$ \\
Steam turb.-MDO & 6,25 & 0,6 & 3200 & 0,5 & 3 & 2,08 \\
HS diesel eng. & 70 & 9 & 3200 & 3,5 & $20 \mathrm{~s}$ \\
Med. speed diesel eng. & 57 & 7,4 & 3200 & 2,4 & 1,2 & $20 \mathrm{~s}$ \\
Slow speed diesel eng. & 87 & 7,4 & 3200 & 2,4 & 1,2 & $20 \mathrm{~s}$ \\
Gas turb. & 16 & 0,5 & 3200 & 0,2 & 1,1 & $20 \mathrm{~s}$ \\
Pleasure-Inboard diesel & 48 & 20 & 3200 & 26 & Neg. & $20 \mathrm{~s}$ \\
Pleasure-Inboard gasoline & 21,2 & 201 & 3000 & 13,9 & Neg. & $20 \mathrm{~s}$ \\
Outboard gasoline eng. & 1,07 & 540 & 3000 & 176 & Neg. & $20 \mathrm{~s}$ \\
\hline
\end{tabular}


Table 3.Principle data of MV. Meratus Mamiri

\begin{tabular}{ll}
\hline Ship name/type & MV. Meratus mamiri/container \\
\hline Dimension (LOA; B; T) & $149.58 ; 23.1 ; 8.6 \mathrm{~m}$ \\
Vessel Speed (Service) & $16 \mathrm{knot}$ \\
Main engine (Unit, Type, Power, SFOC) & $1 \mathrm{xMAN}$ B\&W 7S50MC, 13610 HP, $170 \mathrm{gr} / \mathrm{kWh}$ \\
Auxiliary engine (Unit, Type, Power, SFOC) & $3 x$ Ssangyong-Sulzer 6S20, 1961 HP, 200 gr/kWh \\
GT & 11964 Tones \\
Routes & Tj. Priok Port Jakarta-Tj. Perak Port Surabaya \\
\hline
\end{tabular}

Table 4.Ports Distance

\begin{tabular}{llll}
\hline Port & Port Area 1 $(\mathrm{nm})$ & Sea Area $(\mathrm{nm})$ & Port Area 2 $(\mathrm{nm})$ \\
\hline Tj. Priok-Tj. Perak & 10 & 338 & 25 \\
\hline
\end{tabular}

Emissions are calculated by considering factors such as engine and fuel type of each type of fuel. Pitana et al. (2010) has shown that emission rate can be calculated using Equation 3 as below.

$E=\operatorname{Sxt} F$

Where:

$E=$ The total emission of pollutants $(\mathrm{kg})$

$S=$ The fuel consumption (ton/hours)

$F=$ The emission factor $(\mathrm{kg} /$ ton of fuel $)$

Pitana et al. (2010) has shownthe emission factor of each pollutant in units of $\mathrm{kg}$ per ton fuel and the type of ship engines in Table 2.

\section{Research Methods}

The research methods contain of some steps that will be described in the following section as below. The object of this paper is using MV. Meratus Mamiri.

Table 3 Show the principle dimension of MV. Meratus Mamiri and Table 4 show the distance area in Tanjung Perak port and Tanjung priok port.

To calculate the duration of sailing vessel can use Equation 1. The calculation of fuel consumption of engines can use formula as in Equation 2. Emissions are calculated by considering factors such as engine and fuel type of each type of fuel. Emission rate can be calculated using Equation 3.

\section{Result and Discussion}

The ship's speed will be varied in order to see the effect of the speed difference on duration of sailing, fuel consumption and exhaust emissions from the ships. Speed variation is based on the area of cruise ships, the speed of the port area 1 , the speed of the sea area and the speed of the port area 2. Speed variations can be seen in Table 5 .
Table 5. Variations speed of MV. Meratus Mamiri

\begin{tabular}{ll}
\hline Speed variation $(\mathrm{kn})$ & Speed variation $(\mathrm{kn})$ \\
\hline $6-18.2-6$ & $7-18.2-7$ \\
$6-18.7-6$ & $7-18.7-7$ \\
$6-19.2-6$ & $7-19.2-7$ \\
$6-19.7-6$ & $7-19.7-7$ \\
$6-20.2-6$ & $7-20.2-7$ \\
\hline
\end{tabular}

Tj. Priok 0

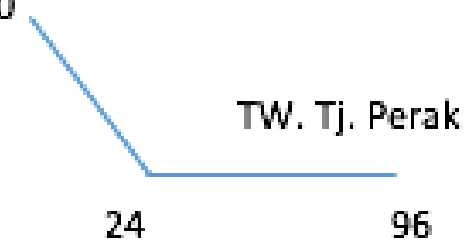

Fig. 1. Time window of Tanjung Perak's port

The case study of MV. Meratus Mamiri operating on the route $\mathrm{Tj}$. Priok-Tj. Perak. At the port that will pass, the vessel has a time windows schedule that must be obeyed. When the ship arrives at the port prior to the schedule will be subject to a charge, as well as if the ship passed through the service schedule will be subject to charge anyway. Thus, in a cruise ship can be set when running at high speed and when the ship running at low speed. Figure 1 shows the time window in the harbor $\mathrm{Tj}$. Perak.

Services time of Tanjung Perak is $72 \mathrm{~h}$, with a demand of port 800 TEUs and queue times (port time) is assumed to harbor idle time is $35 \mathrm{~h}$. Using Equation 4 below, it can be seen that the time of loading and unloading of MV. Meratus Mamiri is $26.6 \mathrm{~h}$ :

$T_{L / U}=(T E U s) /$ Capacity of crane in Portx 2

After knowing all the variables needed, the next step is to calculate the sailing duration of ship, fuel 
consumption and exhaust gas emissions produced by ship. The calculation of sailing duration of the ship aims to find out how long it takes in one trip. The duration of the ship calculated in accordance with the area and variations in speed that has been modeled in Table 5. Calculation results shown in Table 6 . Table 6 it can be seen that the speed of the service vessel, the duration needed for the variation speed of 4-16-4 kn takes sailing for $39.9 \mathrm{~h}$, while for the variation speed of 5-16-5 kn takes sailing for $28.1 \mathrm{~h}$.

After calculating the sailing duration at any speed variation. Next is to analyze the effect of speed changes on fuel consumption on ships. In theory the ship at low speed then produce more fuel consumption slightly. Table 7 shows the results of the calculation of the total fuel consumption on MV Meratus Mamiri at variation of speed that has been previously assumed.

Ship fuel consumption is known, then the amount of exhaust emissions produced ships can also be known. Theoretically the amount of fuel consumption is directly proportional to the amount of emissions produced. If high fuel consumed, the amount of exhaust emissions produced is also high. Table 8 shows the results of the calculation of the amount of emissions released MV. Meratus Mamiri on every variation of speed that has been previously assumed. Emissions that are released in the form of ship NOx, $\mathrm{CO}, \mathrm{CO}_{2}, \mathrm{VDC}, \mathrm{SOx}$ and PM.

Table 7 shown that at a speed of servicing ships varied at 4-16-4 kn 35.7 tons of fuel needed during the trip duration of 29.9 hours, while in the service speed of the ship is varied at 5-16-5 kn 35.8 tons of fuel needed for the duration of the trip 28.1 hours.

Table 8 shown that at a speed of servicing ships varied at 4-16-4 kn with a fuel consumption of 35.7 tons of fuel and trip duration of $29.9 \mathrm{~h}$, the exhaust gases produced is $2036 \mathrm{~kg} /$ tonne of fuel NOX, 264 $\mathrm{kg} /$ ton of fuel CO, $86 \mathrm{~kg} / \mathrm{ton}$ of fuel VOC, 114306 $\mathrm{kg} /$ ton of fuel $\mathrm{CO}_{2}$ and $48 \mathrm{~kg} /$ ton of fuel PM. While in the service speed of the ship is varied at 5-16-5 $\mathrm{kn}$ with fuel consumption of 35.8 tons and $28.1 \mathrm{~h}$ trip duration, the exhaust gases produced is $2039 \mathrm{~kg} /$ tonne fuel NOX, $265 \mathrm{~kg} /$ ton of fuel CO, $86 \mathrm{~kg} / \mathrm{ton}$ of fuel VOC, 114490 $\mathrm{kg} /$ ton of fuel $\mathrm{CO}_{2}$ and $48 \mathrm{~kg} /$ ton of fuel PM.

From the above calculation, it was concluded that the speed greatly affect fuel consumption and exhaust. emissions produced. Each ship in the fleet has a service speed which is normally used shipping companies plan routes and schedules to dock. However, in reality, the ship can sail at a speed of others as well sailing.

Table 6. Duration calculation of MV. Meratus Mamiri with variation speed in each area

\begin{tabular}{llllllll}
\hline Speed $(\mathrm{kn})$ & $\begin{array}{l}\text { Port area } \\
\text { 1st }(\mathrm{nm})\end{array}$ & $\begin{array}{l}\text { Sea area } \\
(\mathrm{nm})\end{array}$ & $\begin{array}{l}\text { Port area } \\
\text { 2nd }(\mathrm{nm})\end{array}$ & $\begin{array}{l}\text { Duration }(\mathrm{h}) \\
-------------\end{array}$ & Total (h) \\
\hline $4-15-4$ & 10 & 338 & 25 & 2.5 & 22.5 & 6.3 & 31.3 \\
$4-15.5-4$ & 10 & 338 & 25 & 2.5 & 21.8 & 6.3 & 30.6 \\
$4-16-4$ & 10 & 338 & 25 & 2.5 & 21.1 & 6.3 & 29.9 \\
$4-16.5-4$ & 10 & 338 & 25 & 2.5 & 20.5 & 6.3 & 29.2 \\
$4-17-4$ & 10 & 338 & 25 & 2.5 & 19.9 & 6.3 & 28.6 \\
$5-15-5$ & 10 & 338 & 25 & 2.0 & 22.5 & 5.0 & 29.5 \\
$5-15.5-5$ & 10 & 338 & 25 & 2.0 & 21.8 & 5.0 & 28.8 \\
$5-16-5$ & 10 & 338 & 25 & 2.0 & 21.1 & 5.0 & 28.1 \\
$5-16.5-5$ & 10 & 338 & 25 & 2.0 & 20.5 & 5.0 & 27.5 \\
$5-17-5$ & 10 & 338 & 25 & 2.0 & 19.9 & 5.0 & 26.9 \\
\hline
\end{tabular}

Table 7. Calculation result of fuel consumption MV. Meratus Mamiri

\begin{tabular}{lll}
\hline Speed variations (knot) & Duration (hours) & Total of fuel consumption (Ton) \\
\hline $4-15-4$ & 31.3 & 32.1 \\
$4-15.5-4$ & 30.6 & 33.9 \\
$4-16-4$ & 29.9 & 35.7 \\
$4-16.5-4$ & 29.2 & 37.6 \\
$4-17-4$ & 28.6 & 39.6 \\
$5-15-5$ & 29.5 & 32.2 \\
$5-15.5-5$ & 28.8 & 33.9 \\
$5-16-5$ & 28.1 & 35.8 \\
$5-16.5-5$ & 27.5 & 37.7 \\
$5-17-5$ & 26.9 & 39.6 \\
\hline
\end{tabular}


Ayudhia P. Gusti and Semin / American Journal of Engineering and Applied Sciences 2016, 9 (4): 1046.1053 DOI: 10.3844/ajeassp.2016.1046.1053

Table 8. Emissions calculation results of MV. Meratus Mamiri

Speed Total of fuel

Variation (kn) Duration (h) Cons. (Ton)

4-15-4 31.3

4-15.5-4 $\quad 30.6$

$\begin{array}{ll}\text { Cons. (Ton) } & \text { NOx }(\mathrm{kg}) \\ 32.1 & 1830\end{array}$

33.9

4-16-4

35.7

1931

2036

37.6

4-16.5-4 29.2

39.6

$4-17-4$

28.6

29.5

5-15.5-5 28.8

5-16-5 28.1

5-16.5-5

27.5

32.2

33.9

35.8

37.7

39.6

2144

2256

1834

1935

2039

2147

2259

CO (kg)

VOC $(\mathrm{kg})$

$\mathrm{CO}_{2}(\mathrm{~kg})$

10275

10843

11430

264

278

12037

12664

10294

238

10861

11449

251

265
279

293

12055

12682 PM (kg)

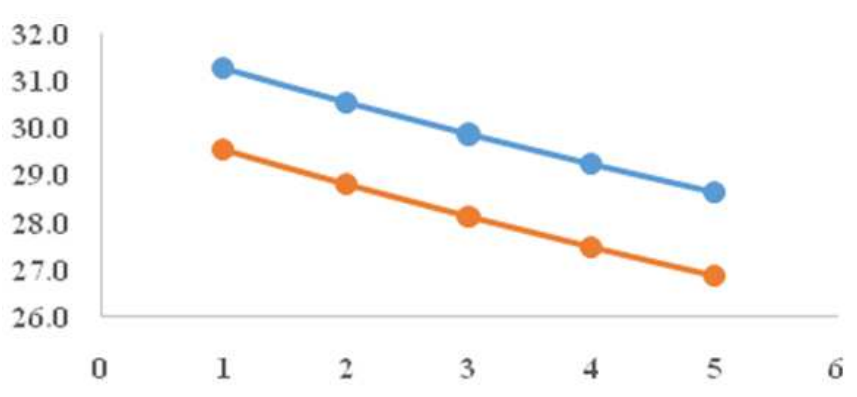

$\longrightarrow$ Speed vs Duration 1st $\longrightarrow$ Speed Vs Duration 2nd

Fig. 2. Relation between speed and duration

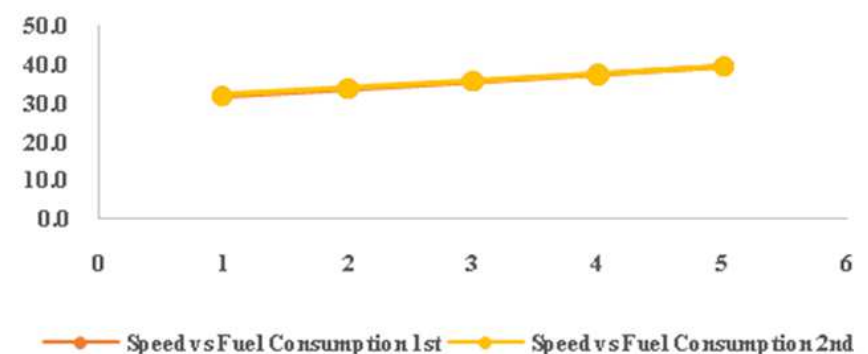

Fig. 3. Relation between Speed and Fuel Consumption

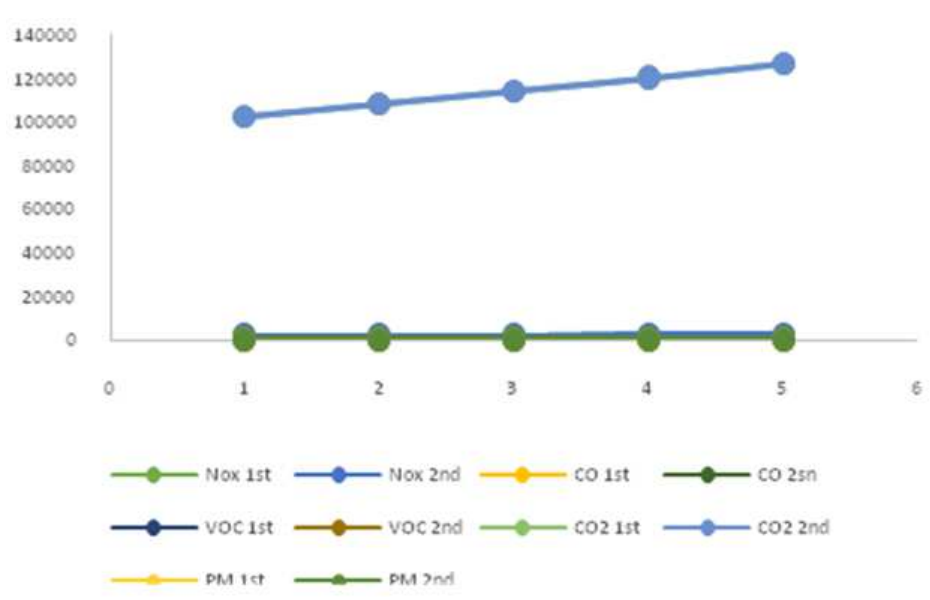

Fig. 4. Relation between Speed and Exhaust Emissions 


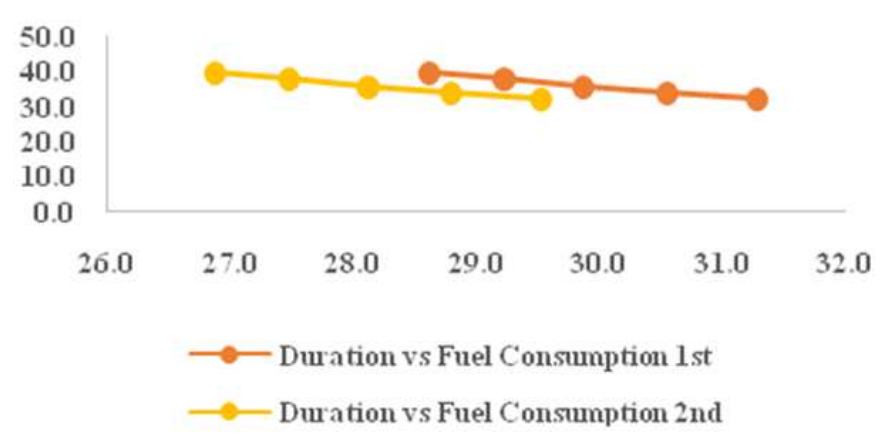

Fig. 5. Relation between duration and fuel consumption

From the above calculation, it was concluded that the speed greatly affects fuel consumption and exhaust emissions produced. Each ship in the fleet has a service speed which is normally used shipping companies plan routes and schedules to dock. However, in reality, the ship can sail at a speed of others as well. Sailing boats at a distance (s) and the particular time because it will affect the cost of fuel consumption is highly dependent on the speed. Here was the influential role of speed optimization. With more optimal speed settings, ships can save fuel consumption and impact on the environment due to exhaust emissions can also be reduced.

Below are some charts that showing the relationship between speed and duration speed and fuel consumption, as well as the speed and exhaust emissions.

Figure 2 shows that the faster the ship, the duration of which will be reached more quickly. The blue line shows the graph for the speed of 4 knots in every area of the port, while the orange line shows the graph to a speed of 5 knots in every area of the port.

Figure 3 shows that the speed is directly proportional to fuel consumption, the faster the boat, the fuel consumption is also higher. Graph velocity variations in the port area at a speed of 4 knots coincide with chart speed of 5 knots. That is because the difference in fuel consumption is not too large.

Figure 4 shows that the exhaust emissions are a function of fuel consumption, the faster the boat, the fuel consumption is also higher, so is the emissions produced.

Figure 5 shows that the faster the duration of the cruise ship, the higher fuel consumption. If the objectives are to reduce fuel consumption and exhaust emissions, keep in mind that each vessel has a specific time window. When the ship arrives at the port prior to the schedule it will be fined, as well as if the ship passed through the service schedule it will be fined as well. Thus, in a cruise ship can be set when running at high speed and when the ship running at low speed.

\section{Conclusion}

The reducing in fuel costs can provide big savings on the total cost of the vessel. One of the alternatives is sailing at low speeds. Due to the non-linear relationship between speed and fuel consumption, it is clear that a ship with running slower would consume less fuel than the ships that run faster. This research is the basis of the development of speed optimization to reduce fuel consumption and exhaust emissions for domestic ship in Indonesia. The result of this study shows that ship speed affect the fuel consumption and exhaust gas emissions. By optimizing speed in each port area, ship can reduce the fuel consumption and exhaust emission than sailing in service speed that given by shipping company.

The future research of this study is the use of algorithms for optimizing the speed.

\section{Acknowledgement}

In this paper the authors very express the acknowledgement to Department of Marine Engineering, Research Institute and Marine Technology Doctoral Program of Institut Teknologi Sepuluh Nopember, Surabaya Indonesia for the support of this research.This research was carried out with financial support from Doctoral Program Master's Degree Superior (PMDSU) Scholarship, funded by Indonesian Directorate General of HigherEducation (DIKTI).

\section{Author's Contributions}

Ayudhia P. Gusti: Participated in all data analysis and contributed to the writing of the manuscript.

Semin: Contributed in substantial revision and improvement of the draft of the paperand contributed to the writing of the manuscript.

\section{Ethics}

Authors have read and approved the publication of this article. There are no ethical issues arising out of the publication of this paper. This work is purely original and no part of it has been published earlier anywhere in any form. 


\section{References}

Ismail, A.R., R.A. Bakar, S. Ali and I. Ali, 2008a. Computer modelling for 4-stroke direct injection diesel engine. Adv. Mater. Res., 33-37: 801-806. DOI: 10.4028/www.scientific.net/AMR.33-37.801

Ismail, R.A. Bakar and Semin, 2008b. An investigation of valve lift effect on air flow and $C D$ of four stroke engines based on experiment. Am. J. Applied Sci., 5: 963-971. DOI: 10.3844/ajassp.2008.963.971

Bi, Y., J.S. Yuan and Y. Jin, 2015. Beyond the interconnections: Split manufacturing in RF designs. Electr. J., 4: 2079-9292.

DOI: 10.3390/electronics4030541

Eide, M., S. Dalsoren, O. Endresen, B. Samset and G. Myhre et al., 2013. Reducing $\mathrm{CO}_{2}$ from shippingdo non- $\mathrm{CO}_{2}$ effects matter? Atmospheric Chem. Phys., 13: 4183-4201.

DOI: $10.5194 / \mathrm{acp}-13-4183-2013$

Fagerholt, K., G. Laporte and I. Norstad, 2010. Reducing fuel emissions by optimizing speed on shipping routes. J. the Operat. Res. Society, 61: 523-529. DOI: 10.1057 jors.2009.77

Lindstad, H., G. Eskeland, H. Psaraftis, I. Sandaas and A. Stromman, 2015. Maritime shipping and emissions: A three-layered, damage-based approach. Ocean Eng., 110: 94-101.

DOI: 10.1016/j.oceaneng.2015.09.029

Norstad, I., K. Fagerholt and G. Laporte, 2010. Tramp ship routing and scheduling with speed optimization. Transport. Res., 19: 853-865.

DOI: $10.1016 /$ j.trc.2010.05.001

Pitana, T., E. Kobayashi and N. Wakabayashi, 2010. Estimation of exhaust emissions of marine traffic using Automatic Identification System data (case study: Madura Strait area, Indonesia). Proceedings of the IEEE - Sydney OCEANS, May 24-27, IEEE Xplore Press, pp: 1-6.

DOI: $10.1109 /$ OCEANSSYD.2010.5603866

Psaraftis, H. and C. Kontovas, 2014. Ship speed optimization: concepts, models and combined speed-routing scenarios. Transport. Res. Part C, 44: 52-69. DOI: 10.1016/j.trc.2014.03.001

Semin, R.A. Bakar and A.R. Ismail, 2008a. Computational visualization and simulation of diesel engines valve lift performance using CFD. Am. J. Applied Sci., 5: 532-539.

DOI: 10.3844 ajassp.2008.532.539

Semin, A.R. Ismail and R.A. Bakar, 2008b. Comparative performance of direct injection diesel engines fueled using GAS based on GT-POWER simulation. Am. J. Applied Sci., 5: 540-547.

DOI: 10.3844 /ajassp.2008.540.547
Semin, R.A. Bakar and A.R. Ismail, 2008c. Investigation of diesel engine performance based on simulation. Am. J. Applied Sci., 5: 610-617. DOI: 10.3844/ajassp.2008.610.617

Semin, A.R. Ismail, R.A Bakar and I. Ali, 2008d. Heat transfer investigation of intake port engine based on steady-state and transient simulation. Am. J. Applied Sci., 5: 1572-1579.

DOI: 10.3844 /ajassp.2008.1572.1579

Semin, A.R. Ismail and R.A. Bakar, 2008e. Investigation of GAS engine intake port gas flow temperature based on steady-state and transient simulation. Eur. J. Scientific Res.

Semin, R.A Bakar and A.R. Ismail, 2009a. Compressed natural gas as an alternative fuel for internal combustion engines: A technical review. Int. Rev. Mech. Eng.

Semin, A. Idris and R.A Bakar, 2009b. Effect of port injection GAS engine using injector nozzle multi holes on air-fuel mixing in combustion chamber. Eur. J. Scientific Res., 34: 16-24.

Semin, A.R. Ismail and R.A. Bakar, 2009c. Gas fuel spray simulation of port injection compressed natural gas engine using injector nozzle multi holes. Eur. J. Scientific Res., 29: 188-188.

Semin, A. Idris, R.A. Bakar and A.R. Ismail, 2009d. Study of the engine cylinder fluid characteristics for diesel engine converted to GAS engine. Eur. J. Scientific Res.

Semin, A.R. Ismail and T.F. Nugroho, 2010. Experimental and computational of engine cylinder pressure investigation on the port injection dedicated GAS engine development. J. Applied Sci., 10: 107-115. DOI: 10.3923/jas.2010.107.115

Semin, 2012. Injector nozzle spray on compressed natural gas engines: A technical review. Int. Rev. Mech. Eng., 6: 1035-1043.

Semin and R.A. Bakar, 2013. Simulation and experimental method for the investigation of compressed natural gas engine performance. Int. Rev. Mech. Eng.

Semin and R.A. Bakar, 2014. Computational modelling the effect of new injector nozzle multi diameter holes on fuel-air mixing homogeneous of GAS engine. Int. J. Applied Eng. Res., 9: 9983-9988.

Semin, 2015a. Analysis of biogas as an alternative fuel for electric generator engine in Bawean IslandIndonesia. Int. J. Applied Eng. Res., 10: 3531335317.

Semin, 2015b. Investigation the effect of injector nozzle multi holes geometry on fuel spray distribution flow of GAS engine based on computational modeling. Int. J. Applied Eng. Res. 
Semin, B. Cahyono, Amiadji and RA Bakar, 2015. Air-fuel mixing and fuel flow velocity modeling of multi holes injector nozzle on CNG marine engine. Proc. Earth Planetary Sci., 14: 101-109. DOI: 10.1016/j.proeps.2015.07.090

Valentino, F., S. Gurning and A. Dinariyana, 2012. Optimasi skenario bunkering dan kecepatan kapal pada pelayaran tramper. J. Teknik Pomits, 1: 1-5.
Yuan, J.S., Y. Xu, S.D. Yen, Y. Bi and G.W. Hwang, 2014. Hot carrier injection stress effect on a $65 \mathrm{~nm}$ LNA at $70 \mathrm{GHz}$. IEEE Trans. Device Mater. Reliability, 14: 1530-4388. DOI: 10.1109/TDMR.2014.2328496

Yuan, J.S. and Y. Bi, 2015. Process and temperature robust voltage multiplier design for RF energy harvesting. Microelectron. Reliability, 55: 107-113. DOI: 10.1016/j.microrel.2014.09.024 